Available online at http://iddtonline.info

RESEARCHARTICLE

\title{
INVESTIGATION ON THE PRODUCTION OF L-GLUTAMINASE FROM PSEUDOMONAS STUTZERI STRAIN UNDER SOLID STATE FERMENTATION USING VARIOUS AGRO RESIDUES
}

\author{
Athira R. N., T. Elizebeth, T. Narendra, Sheik Tanweer Ahmed, Shankar Kumar Gupta, \\ Manoj Chaudary, Siddalingeshwara K.G., Pramod T.* \\ Dept. of Microbiology, Padmashree Institute of Management and Sciences, Kengeri, Bangalore- 560060 \\ *Corresponding author's Email: drpramodtaranath@gmail.com
}

\begin{abstract}
Solid state fermentation was carried out for the production of L-glutaminase by Pseudomonas stutzeri PIMS6 using different agro residues including green gram husk, Bengal gram husk, cattle feed, wheat bran and groundnut oil cake as solid substrates. L-glutaminase has received significant attention in recent years owing to its potential applications in medicine as an anticancer agent, as an efficient anti-retroviral agent and as a biosensor. In food industries it is used as a flavor and aroma enhancing agent. The maximum yield (55.24 U/gds) of L-glutaminase by Pseudomomonas stutzeri PIMS6 was obtained using cattle feed at $75 \%$ initial moisture content, initial $\mathrm{pH} 8.0$, supplemented with glucose (1.0\%), ammonium sulphate (1.0\%), inoculated with $5 \%$ of inoculum and incubated at $37^{\circ} \mathrm{C}$ for $96 \mathrm{~h}$. Both physico-chemical and nutritional parameters played a significant role in the production of the enzyme L-glutaminase.
\end{abstract}

Keywords: L-glutaminase, Pseudomonas stutzeri PIMS6, Cattle feed, Solid state fermentation.

\section{INTRODUCTION}

L-glutaminase (EC.3.5.1.2) is an amidohydrolase which catalyses the hydrolytical deamination of L-glutamine resulting in the production of L-glutamic acid and ammonia. L-Glutaminases are ubiquitous in the biological world ${ }^{1-2}$ and organisms ranging from bacteria to human beings have the enzyme. L-Glutaminase has a central role in mammalian tissues ${ }^{3}$. These are generally categorized as the kidney type and liver type glutaminases and both the types have been purified and characterized $^{4-6}$. Interest on amidohydrolases started with the discovery of their anti-tumour properties ${ }^{7-10}$ and since then, a lot of efforts have gone into extensive studies on microbial L-glutaminases with the intention of developing them as antitumor agents.

Cancer, particularly leukemia, is a global problem and in spite of sincere efforts paid in the past, search for efficient drugs to solve this problem is being continued worldwide. Interest in amidohydrolases such as L-glutaminase started with the discovery of their antitumour properties. Tumors compete for nitrogen compounds. Glutamine is an efficient vehicle for the transport of nitrogen and carbon skeletons between the different tissues in the living organism ${ }^{11}$. Tumor inhibition is mediated by inhibition of both nucleic acid and protein synthesis of tumor cells. As specific inhibition of tumor cell glutamine uptake could be one of the possible ways to check the growth. Use of Lglutaminase enzyme as a drug has gained much importance. Only a limited number of microbial enzymes, that deplete nutritionally essential amino acids, such as asparaginases ${ }^{12}$, glutaminases 13 and carboxypeptidase ${ }^{14}$ have been suggested for the treatment of human leukemia's and solid tumors. In this context Lasparaginases and L-glutaminases have received greater attention with respect to their antileukemic effect ${ }^{15}$

A parallel interest on microbial L-glutaminases stemmed from its applications in food flavouring, especially in the soy sauce and related industries of the orient, which initiated the quest for industrial sources of the enzyme. With the development of biotechnology, microbial L-glutaminases found newer applications in clinical analysis and even in manufacture of metabolites. Another important application of L-glutaminase is in biosensors for monitoring glutamine levels in mammalian and hybridoma cell cultures without the need of separate measurement of glutamic acid ${ }^{16}$

While commercial production of glutaminase is carried out using submerged fermentation (SmF) technique, using natural substrates or agricultural byproducts/residues has also gained much attention due to its various advantages over SmF. In recent years, solid state fermentation (SSF) has emerged as a promising technology for the development of several bioprocesses which include the production of industrial enzymes on a large scale.

In the present study we report the production of L-glutaminases from a novel Pseudomonas stutzeri PIMS6 strain using cattle feed as a novel substrate.

\section{MATERIALS AND METHODS}

\section{Isolation of strains}


A total of 13 soil samples were taken, the samples were serially diluted and inoculated on to nutrient agar medium. The inoculated plates were incubated at $37^{\circ} \mathrm{C}$ for $24-48 \mathrm{~h}$. In all a total of 24 isolates were obtained, out of which 16 were bacteria. The study was continued with the bacterial strains (Plate-1). Colonies were selected on pigmentation and colony morphology, and sub-cultured on fresh nutrient agar medium for further studies (Table -1).

The 16 bacterial isolates were subjected to rapid plate assay method for screening of L-glutaminase production as per the method of ${ }^{17}$. The nutrient agar medium containing $\left(\mathrm{gL}^{-1}\right)$ peptone 5 , Beef extract 3, sodium chloride 5 and Agar 15 was used in the screening process. The medium was supplemented with phenol red dye $(2.5 \%$ solution prepared in ethanol and $\mathrm{pH}$ was adjusted to 7.0), autoclaved and plates were prepared. Control plates were prepared without L-glutamine (instead containing $\mathrm{NaNO}_{3}$ as the nitrogen source). The plates were centrally inoculated with $100 \mu \mathrm{l}$ of suspension of the isolates and incubated at $37^{\circ} \mathrm{C}$. The zone and colony diameter (Plate-2) were measured after every $24 \mathrm{~h}$ interval. Among them 8 strains were Lglutaminase producers, the strain producing the maximum zone of hydrolysis was taken for further studies.

\section{Collection of substrates}

Various agro-industrial waste substrates and their extracts were evaluated for the production of Lglutaminase under solid state. A total of five different substrates like green gram husk, Bengal gram husk, cattle feed, wheat bran and groundnut cake (Plate-3) were examined for enzyme production. All the substrates used in the study were procured from the local market.

\section{Screening of substrates for L-glutaminase production}

Various agro residues were screened for the production of L-glutaminase through solid-state fermentation (SSF) employing Pseudomonas stutzeri PIMS6. Twenty grams of each of the above substrates (green gram husk, Bengal gram husk, groundnut cake, wheat bran and cattle feed) were taken in $250 \mathrm{ml}$ Erlenmeyer flask and rehydrated to $75 \%$ of moisture content by adding sterile distilled water. The cotton plugged flasks were autoclaved at $121^{\circ} \mathrm{C}$ for $15 \mathrm{~min}$ and allowed to cool at room temperature. The contents of the flasks were inoculated with $1 \mathrm{ml}$ of inoculum. The flasks were mixed thoroughly by gently beating on the palm of the hand and thus prepared flasks were kept in slanting position and incubated at $37^{\circ} \mathrm{C}^{18}$.

Optimization of various process parameters required for maximum L-glutaminase production by Pseudomonas stutzeri PIMS6 was performed. The parameters studied for solid state included moisture, initial $\mathrm{pH}$ (6-11) of the medium, temperature of incubation $\left(25-37^{0} \mathrm{C}\right)$, inoculum size $(1-5 \%)$. The procedure adopted for optimization of various parameters influencing L-glutaminase production was to evaluate the effect of independent parameters keeping others constant and to incorporate it at the optimized level in the next experiment while optimizing another parameter.

\section{Extraction of crude enzyme}

One gram of the fermented substrate was taken out aseptically from the flasks. The substrate was dispensed in a beaker containing $10 \mathrm{~mL}$ of distilled water and kept on a rotary shaker (160 rpm) for 1 hour. The extract was filtered and centrifuged as mentioned earlier. The supernatant thus obtained was used as crude extract for L-glutaminase assay.

\section{Assay of L-glutaminase}

Assay of enzyme was carried out as per Imada et al., ${ }^{19}$. $0.5 \mathrm{ml}$ of $0.04 \mathrm{M} \mathrm{L}$-glutamine was taken in a test tube, to which $0.5 \mathrm{ml}$ of $0.05 \mathrm{M}$ buffer (Tris- $\mathrm{HCl}$ buffer $\mathrm{pH} 7.2$ ), $0.5 \mathrm{ml}$ of enzyme and $0.5 \mathrm{ml}$ of distilled water was added to make up the volume to $2 \mathrm{ml}$ and the reaction mixture was incubated for $30 \mathrm{~min}$ at $37^{\circ} \mathrm{C}$. After the incubation period the reaction was stopped by adding $0.5 \mathrm{ml}$ of 1.5 $\mathrm{M}$ trichloroacetic acid (TCA). $0.1 \mathrm{ml}$ was taken from the above reaction mixture and added to $3.7 \mathrm{ml}$ of distilled water and to that $0.2 \mathrm{ml}$ of Nessler's reagent was added and incubated for $15-20 \mathrm{~min}$ at $20^{\circ} \mathrm{C}$. The O.D was measured at $450 \mathrm{~nm}$. The blank was prepared without adding enzyme. The enzyme activity was expressed in international unit (IU).

\section{Effect of initial moisture content on L-glutaminase production}

A set of conical flasks containing $20 \mathrm{~g}$ substrate (cattle feed) were moistened with an appropriate amount of distilled water in order to obtain different moisture levels like 55, 60,65,70,75 and $80 \%$. The contents were autoclaved at $121^{\circ} \mathrm{C}$ for $20 \mathrm{~min}$. and inoculate each flask with one $\mathrm{ml}$ of inoculums of Pseudomonas stutzeri PIMS6. Thus prepared flasks were mixed thoroughly and incubated in a humidity chamber at $37^{\circ} \mathrm{C}$ for a period of 5 days ${ }^{18}$.

\section{Effect of initial pH on L-glutaminase production}

To determine the effect of initial $\mathrm{pH}$ on Lglutaminase production, a set of six conical flasks each containing $20 \mathrm{~g}$ of cattle feed was used. The $\mathrm{pH}$ range of the study was 6-11 with an increment of 1 . The desired $\mathrm{pH}$ level was adjusted using dilute $(0.1 \mathrm{~N}) \mathrm{NaOH} / \mathrm{HCl}$. Thus prepared flasks were autoclaved and inoculated with the spore suspension of Pseudomonas stutzeri PIMS6. The flasks were then incubated at $37^{\circ} \mathrm{C}$ in a incubator.

\section{Effect of incubation temperature on L- glutaminase production}

A set of six conical flasks each containing 100 $\mathrm{ml}$ of extract, was adjusted to $\mathrm{pH} 8.0$, autoclaved and inoculated with the inoculum. The flasks were then incubated at different temperatures ranging from $25^{\circ} \mathrm{C}$ $37^{0} \mathrm{C}$.

\section{Effect of inoculum size on L-glutaminase production}

The conical flasks containing the media at $\mathrm{pH}$ 8.0 were inoculated separately with $1 \mathrm{ml}$ of inoculum 
and incubated at $37^{\circ} \mathrm{C}$. The spore inoculum was prepared at different levels $1-5 \%$ with increments of $1 \%{ }^{20}$.

Effect of supplementation of carbon sources on Lglutaminase production

A set of conical flasks containing $20 \mathrm{~g}$ of cattle feed was supplemented separately with different carbon sources like glucose, maltose, mannitol and lactose. The carbon sources were evaluated at a concentration of $1 \%$ for each carbon source.

Effect of supplementation of nitrogen sources for $L$ glutaminase production

Conical flasks with $20 \mathrm{~g}$ of cattle feed was supplemented with (1\%) nitrogen sources such as ammonium sulphate, yeast extract, ammonium nitrate and peptone.

RESULTS AND DISCUSSION
Out of the 16 cultures, Pseudomonas stutzeri PIMS6 was chosen for glutaminase production as the organism showed positive results in the plate assay. The organism produced pink coloured zones around the colony on media incorporated with phenol red indicator (Plate 1). The medium used for screening was selective for L-glutaminase producer as it contained Lglutaminase as the only carbon and nitrogen source which helped in the direct selection of L-glutaminase producer. The organism produced L- glutaminase in the L-glutamine, glucose containing production medium. Of the five different agro residues cattle feed emerged as the best substrate for further studies (Plate-2). Maximum Lglutaminase activity was achieved may be due to the growth and tolerance to low water activity and high osmotic conditions making Pseudomonas stutzeri PIMS6 efficient for bioconversion of solid substrate.

Table 1: Isolation of Bacterial strains

\begin{tabular}{|c|c|c|c|}
\hline SL.NO. & $\begin{array}{c}\text { SOURCE OF } \\
\text { LOCATION }\end{array}$ & TOTAL ISOLATES & $\begin{array}{c}\text { NO. OF BACTERIAL } \\
\text { STRAINS }\end{array}$ \\
\hline 1. & KERALA & 08 & 05 \\
\hline 2. & MANIPUR & 11 & 07 \\
\hline 3. & PIMS CAMPUS & 05 & 04 \\
\hline & TOTAL & 24 & 16 \\
\hline
\end{tabular}
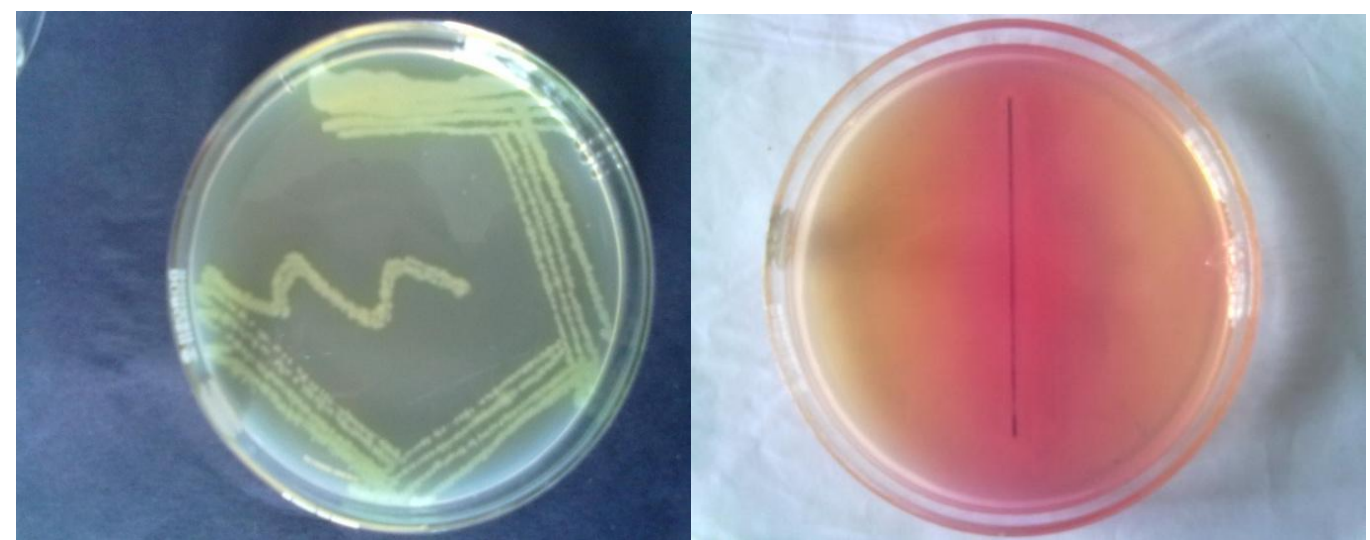

Plate-1 Pseudomonas stutzeri PIMS6 and its Rapid plate assay

Physicochemical parameters- incubation period, temperature, $\mathrm{pH}$ and nutritional parameters- carbon and nitrogen source are the critical factors studied. The physical factors have been the critical components of an industrial or commercial fermentation process, directly affecting the productivity and also the process economics ${ }^{21}$.
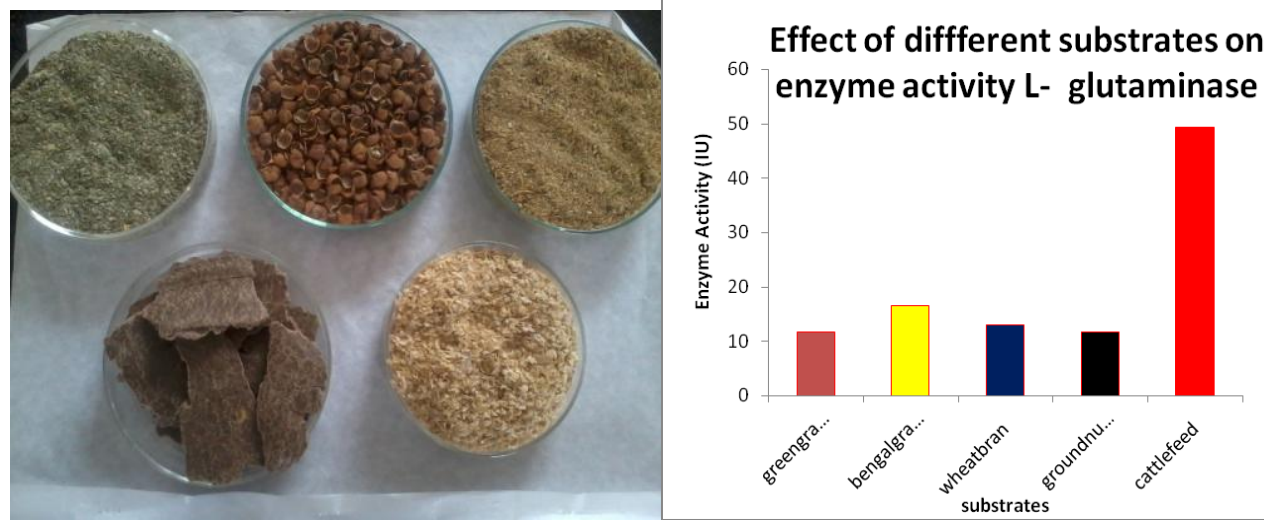

Plate-2 Various substrates and best activity in substrate 
Optimization of physical parameters will not only support good growth but also enhance product yield ${ }^{22}$. Employing Pseudomonas stutzeri PIMS6 L-glutaminase production enhanced with increase in moisture content upto $75 \%$ beyond which it declined ${ }^{23}$. This trend was observed upto $96 \mathrm{~h}$ of fermentation period, highest yield recorded was 55.24 IU Fig-1.

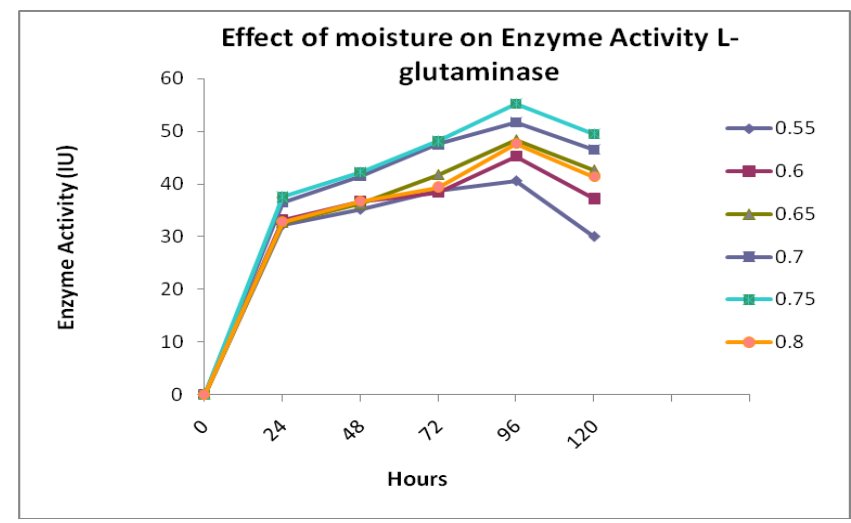

Figure-1 Effect of Moisture

There was a steady increase in the enzyme production as the initial $\mathrm{pH}$ of the medium was raised from 6.0-11, thereafter yield were found to decrease. Maximum acitivity of $59 \mathrm{IU}$ was observed at $\mathrm{pH} 8.0$ at $96 \mathrm{~h}$ of fermentation ${ }^{24}$ Fig-2.

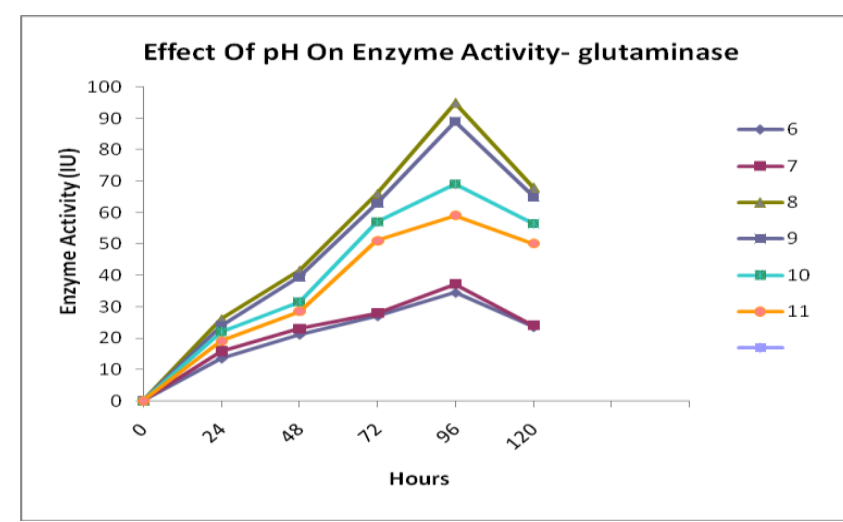

Figure-2 Effect of pH

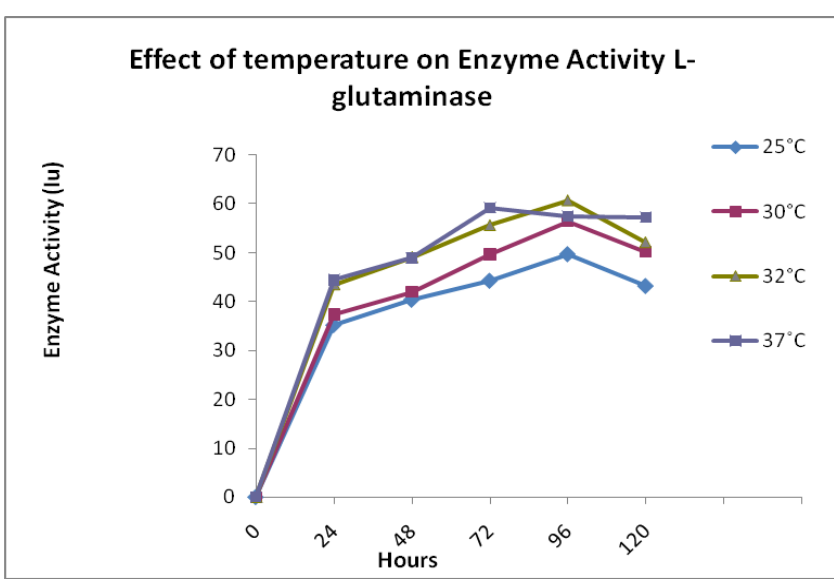

Figure-3 Effect of temperature

Temperature of incubation has shown a considerable impact on L-glutaminase production by Pseudomonas stutzeri PIMS6. Increasing the incubation temperature from $25^{\circ} \mathrm{C}-37^{\circ} \mathrm{C}$ lead to an increase in L-glutaminase production. Temperatures higher than $37^{\circ} \mathrm{C}$ lowered the enzyme yield. The highest L-glutaminase activity 60.67 IU was found at $37^{0} \mathrm{C}$ at $96 \mathrm{~h}$ of incubation ${ }^{24}$ have reported similar results Fig-3.

An inoculum size of 5\% was found to be optimum for the production of L-glutaminase by Pseudomonas stutzeri PIMS6, our results are in accordance to ${ }^{25}$. The enzyme activity observed at the said inoculum size was $67 \mathrm{IU}$ at $96 \mathrm{~h}$ of fermentation Fig-4.

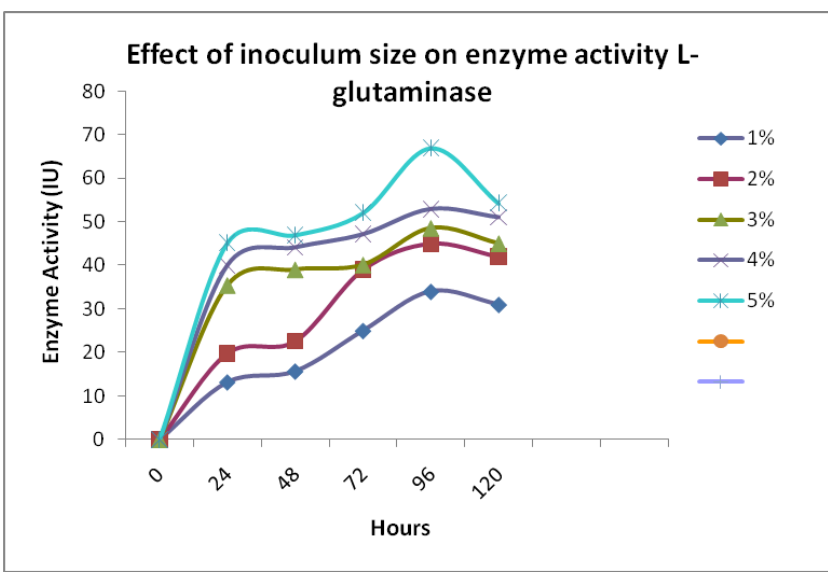

Figure-4 Effect of Inoculum

The process of economization for L-glutaminase production with carbon sources supplementation to the medium was carried out with the concentrations of $1.0 \%$ level. The different carbon sources studied were glucose, mannitol, lactose and maltose,. Among all the carbon sources employed in the present study glucose and lactose significantly increased the enzyme yields whereas maltose and mannitol proved to be detrimental for the production of L-glutaminase. Glucose (1\%) yielded a maximum of $69 \mathrm{IU}$ of L-glutaminase at $96 \mathrm{~h}$ of fermentation ${ }^{24}$ Fig-5.

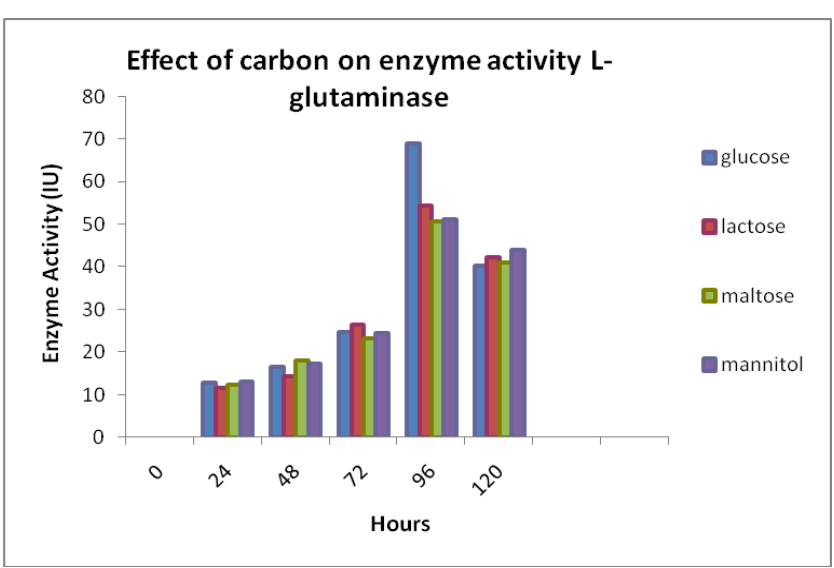

Figure-5 Effect of various carbon sources

There was a considerable increase in the enzyme production when the cattle feed was supplemented with yeast extract, and ammonium sulphate.. Among all the nitrogen sources employed in our study, ammonium sulphate at $1 \%$ was found to be the best, yielding 95.2IU at $96 \mathrm{~h}$ of fermentation, our results are consistent with the findings of ${ }^{26,27}$ Fig-6. 


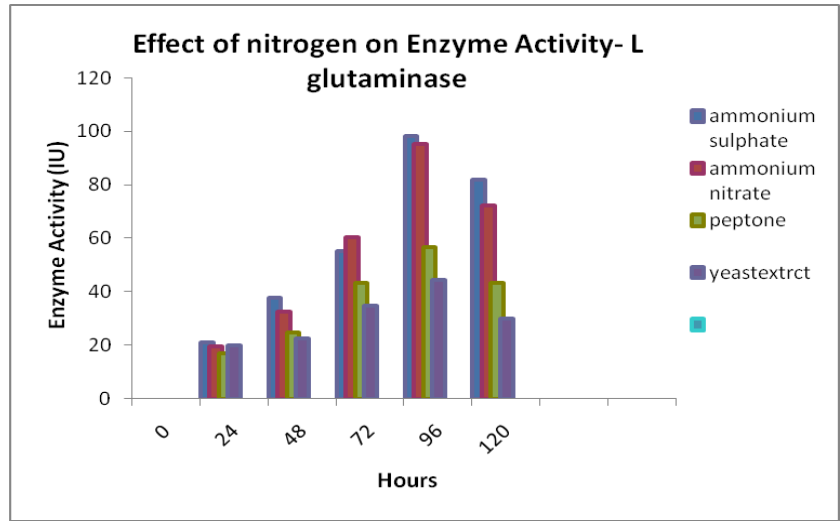

Figure-6 Effect of various nitrogen sources

\section{CONCLUSION}

The strain isolated was from soil was a non pathogenic strain. In this study we report the efficient L-glutaminase

\section{REFERENCES}

1. Oshima M., Yamamoto T. and Soda, K. Further characterization of glutaminase isozymes from Pseudomonas aeruginosa., Agricultural Biological Chemistry, .1976, 40: 2251-2256.

2. Iyer VP and Singhal R.S. Glutaminase Production using Zygosaccharomyces rouxii NRRL-Y 2547: Effect of Aeration, Agitation Regimes and Feeding Strategies. Chem. Eng. Technol, 2010, 33 (1), 55-62.

3. Errera, M. and Greenstein, J.P. (1949), Phosphate activated glutaminase in kidney and other tissues. J.BioI.Chem. 178: 495-502.

4. Svenneby G, Torgner A and Kvamme E. Purification of phosphate dependent pig brain glutaminase, J. Neurochem, 1973, 20: 1217-1224.

5. Curthoys NP, Kuhlenschmidt K. and Godfrey SS. Regulation of renal ammoniagenesis: purification and characterisation of phosphate dependent glutaminase form rat kidney. Arch. Biochem. Biophys, 1976, 74: 82-89.

6. Heini HG, Gebhardt $\mathrm{R}$ and Mecke, D. Purification and characterisation of rat liver glutaminase. Eur. J. Biochem. 1987, 162: 541-546.

7. Broome JD. Evidence the L-asparaginase of activity of guinea pig serum is responsible for its anti lymphoma effects. Nature, 1961, 191: 1114-1115.

8. El-Asmar FA. and Greenberg DM, Studies on the mechanism of inhibition of tumour growth by the enzyme glutaminase. Cancer Res. 1966, 26(1): 116-122.

9. Santana CF, Pinto V, Moreira LC and Lacerda AL. Action of swine kidney L-Glutaminase on Ehrlich carcinoma. Rev. Inst. Antibiot. 1968, 8: 105-107.

10. Roberts J, Holcenberg JS and Dolowy WC. Antineoplastic activity of highly purified bacterial glutaminase, Nature. 1970, 227, 1136-1137.

11. Bertino J R., O'Brien P. and McCullough JL. Inhibition of growth of leukemia cells by enzymic folate depletion, Science. 1971, 172(979), 161

12. Sudha V. Ph.D. Thesis. 1981, Annamalai University, Tamil Nadu, India

13. Chandrasekaran M., Keerthi TR and Maity P, Antineoplastic activity of L-glutaminase produced by marine Pseudomonas sp., Paper presented in 39th Annual Conference of Association of Microbiologists of India, Mangalore, 1998, Dec. 5-7.

14. Roberts J, Mac Allister TW, Sethuraman N. and Freeman A. G, Genetically Engineered Glutaminase and its use in Antiviral and Anti cancer Therapy. 2001, US Patent No. 6312939. producing strain Pseudomonas stutzeri PIMS6. The optimization of physical conditions like moisture, $\mathrm{pH}$, incubation temperature, inoculum size and process optimization with carbon and nitrogen sources has also been studied which will enormously contribute to higher enzyme yield when large scale production is desired. Though there are many reports of L-glutaminase from different microorganisms, bacteria are the most preferred ones. The possibility of obtaining non-allergic source of L-glutaminase from the source that we are reporting cannot be denied, moreover the strain seems to be nonpathogenic.

\section{ACKNOWLEDGEMENT}

Authors would like to thank the authorities of Padmashree Institute of Management and Sciences, Kengeri for providing the facilities to carry out this work.

15. Roberts J, Holcenberg JS.and Dolowy WC, Roberts J., Holcenberg J. S. and Dolowy W. C., Antineoplastic activity of highly purified bacterial glutaminase. Nature 1970, 227 , 1136-1137

16. Sabu Abdul Hameed, Sukumaran Rajeev Kumar and Muthusamy Chandrasekaran. L-glutaminase as a therapeutic enzyme of microbial origin, Methods in Biotechnology. 2002, Vol. 17, Microbial enzymes and Biotransformation, Human Press Inc.

17. Gulati R, Saxena, RK, and Gupta, R.. A rapid plate assay for screening L-asparaginase producing microorganisms. Lett. Appl. Microbiol.1997, 24: 23-26.

18. Lingappa $\mathrm{K}$, and Vivek Babu CS. Optimization of fermentation conditions for lovastatin production in solid state fermentation using Aspergillus terreus . Proc. National Symp. Bioresources. Biotechnology and Bioenterprise. 2004, 291297.

19. Imada A, Igarasi S, Makahana K. and Isono M. Asparaginase and glutaminase activities of microorganisms, Journal of General Microbiology,1973,76, 85-99.

20. Pushpa \& Madhava Naidu, "Protease Production by Aspergillus oryzae in solid state fermentation utilizing coffee by-products". World Applied Sciences Journal. 2010, 8(2): 199-205.

21. Zhang $\mathrm{J}$ and Greasham $\mathrm{R}$, Chemically defined media for commercial fermentations, Appl. Microbial. Biotechnol, $1999,51,407-421$

22. Greasham RL. and Inamine E. Manual of industrial microbiology and biotechnology, Demain A. L. and Soloman M.A. (Eds.), 1986, American Society of Microbiology, Washington D. C.,

23. Lonsane BK, Gildyal NP, Budiatman S and Ramakrishna SV. Engineering aspects of solid state fermentation. Enzyme Microb. Technol. 1985, 7: 258-265.

24. Chitanand MP. and Shete HG.. Condition optimization and production of extracellular L-glutaminase from Pseudomonas fluorescens. Int. J. of Pharma and Bio. Sci. 2012, 3(3):B 155162

25. Mario Khalil Habeeb. Screening of L-Glutaminase produced by actinomycetes isolated from different soils in Egypt. Int. J. Chem. Tech. Res. 2012, 4(4) 1451-1460.

26. Gaffer SA and Shethna YI. . Partial purification and antitumour activity of L-Asparaginase from Azotobacter vinelandi. J. Appl. Microbiol. 1975, 44: 727-729.

27. Albanese E, and. Ka\&ewitz D. Effect of medium composition on the growth and asparaginase production of Vibrio succinogenes. Appl. Environ. Microbiol. 1978. 36:25-30 